\title{
PERBANDINGAN SKOR IQ (Intellectual Question) PADA ANAK STUNTING DAN NORMAL
}

\author{
Wahyu Indah Dewi Aurora ${ }^{1}$, Rico J. Sitorus ${ }^{2}$, Rostika Flora ${ }^{3}$ \\ 1Departemen IImu Kesehatan Masyarakat Fakultas Kedokteran dan IImu Kesehatan Universitas Jambi \\ ${ }^{2}$ Departemen Epidemiologi dan Biostatistik Fakultas Kesehatan Masyarakat Universitas Sriwijaya \\ ${ }^{3}$ Departemen Gizi Masyarakat Fakultas Kesehatan Masyarakat Universitas Sriwijaya \\ Email: auroradr@unja.ac.id
}

\begin{abstract}
ABSTRAK
Introduction: Stunting is a condition in which a child experiences malnutrition or a lack of nutritional intake that lasts a long time (chronic) so that the child becomes short for his age. This situation will naturally result in stunted growth development if left unceasing, and will also affect the quality of his future, especially his intelligence. The incidence of stunting in South Sumatra Province is $26.9 \%$. This figure is of course very high and needs serious attention, given that several theories state that stunting that persists in children over 2 years will have a major impact on children's health.

Methods: This research uses observational analytic research method with unmatching case control design. The study was conducted in three sub-districts in Palembang City, and conducted in August - October 2019 with 150 samples. Data were analyzed by bivariate using chi square analysis.

Results: this study shows that short / stunting children who get an average IQ score of upwards are $64 \%$ and those who get an average IQ score below $36 \%$. Whereas the non-stunted children who get an average IQ score above are $72 \%$ and those who get an average IQ score below are 28\% ( $p=0,000$, OR: 4.57 (95\% Cl: 2,1733 -9,6873).

Conclusion: there is a significant difference in the scores of IQs of stunting and normal children $(p=0,000)$. Children who suffer from stunting are 4.5 times more likely to get below average intelligence compared to children who are not stunting.
\end{abstract}

Keywords: Stunting, Intellectual Question

\footnotetext{
ABSTRAK

Pendahuluan: Stunting merupakansuatu kondisi di mana anak mengalami malnutrisi atau kurangnya asupan gizi yang berlangsung lama (kronis) sehingga mengakibatkan anak menjadi pendek untuk seusianya. Keadaaan ini tentu saja akan mengakibatkan terhambatnya perkembangan pertumbuhan jika dibiarkan terus menerus, dan juga akan mempengaruhi kualitas masa depannya khususnya kecerdasannya. Angka kejadian stunting di Provinsi Sumatra Selatan sebesar $26.9 \%$ Angka ini tentu saja sangat tinggi dan perlu mendapat perhatian serius, mengingat beberapa teori menyebutkan bahwa stunting yang menetap pada anak di atas 2 tahun akan berdampak besar pada kesehatan anak.

Metode: Penelitian ini menggunakan metode penelitian analitik observasional dengan desain unmatching case control. Penelitian dilakukan di tiga kecamatan di Kota Palembang yaitu Kecamatan Seberang Ulu I, Seberang Ulu II dan Sukarame dan dilaksanakan pada bulan Agustus - Oktober 2019 dengan 150 sampel. Data dianalisis dengan bivariate menggunakan analisis chi square.
} 
Hasil: penelitian ini menunjukkan bahwa Anak yang pendek/stunting yang mendapatkan nilai IQ rata-rata ke atas adalah sebesar $64 \%$ dan yang mendapatkan nilai skor IQ rata-rata ke bawah sebesar $36 \%$. Sedangkan pada anak yang tidak stunting yang mendapatkan nilai skor IQ rata-rata ke atas adalah $72 \%$ dan yang mendapat nilai IQ rata-rata ke bawah adalah 28\% ( $p=0.000$, OR:4,57 (95\% Cl:2,1733-9,6873).

Kesimpulan: ada perbedaan signifikan nilai skor IQ anak yang stunting dan normal $(p=0,000)$. Anak yang menderita stunting kemungkinan 4,5 kali mendapatkan kecerdasan rata-rata ke bawah dibandingkan dengan anak yang tidak stunting.

Kata Kunci : Stunting, Kecerdasan intelektual

\section{PENDAHULUAN}

Pengertian stunting atau pendek adalah suatu kondisi di mana anak mengalami malnutrisi atau kurangnya asupan gizi yang berlangsung lama (kronis) sehingga mengakibatkan anak menjadi pendek untuk seusianya. Keadaaan ini tentu saja akan mengakibatkan terhambatnya perkembangan pertumbuhan jika dibiarkan terus menerus, dan juga akan mempengaruhi kualitas masa depannya khususnya kecerdasannya ${ }^{1}$. Kasus stunting ini telah menjadi suatu permasalahan yang teramat penting di hampir seluruh negara di Dunia. Angka kejadian stunting menurut UNICEF mencapai $28 \%$, di mana negara-negara yang ada di ASIA terutama bagian selatan hingga $38 \%$ bahkan prevalensi di Afrika bagian Timur dan Selatan mencapai $40 \%$ ? Prevalensi stunting yang ada di Provinsi Sumatera Selatan berada di di urutan ke $10 \mathrm{di}$ bawah Provinsi Kalimantan Utara, dengan angka prevalensi hingga 26,9\%프. Angka kejadian tersebut tentu masih tinggi dan perlu mendapat perhatian yang lebih serius terutama dampak akan yang terjadi, karena beberapa teori menunjukkan bahwa dampak yang terjadi pada anak stunting dapat menetapa jika lebih dari usia 2 tahun.

Kebutuhan yang harus terpenuhi oleh anak untuk dapat tumbuh dan berkembang salah satunya adalah kesehatannya baik fisik maupu mental ${ }^{4}$. Jika perkembangannya baik maka kan menghasilkan generasi yang cerdas untuk kehidupan mendatang. Kesehatan pada anak tidak lah hanya mengenai penyakit saja, tetapi penting untuk diperhatikan adalah kesehatan fisik, rohani dan sosialnnya, termasuk diantaranya kecerdasan intelekktualnya ${ }^{5}$. Jika anak menderita stunting atau pendek, maka dampak yang akan terjadi juga akan beragam, terutama jika anak sudah masuk usia sekolah atau lebih dari 2 tahun. Jika kondisi malnutrisi kronis ini terus menerus terjadi maka proses tumbuh kembangnya tentu tidak optimal dan dapat terlihat dari kecerdasannya nya ${ }^{6}$. Salah satu untuk menilai dampak yang terjadi pada anak stunting usia sekolah, dapat dinilai kecerdasannya terutama kecerdasan intelektualnya ${ }^{?}$.

Telah banyak literature-literatur yang menyebutkan akan bahaya dari stunting pada anak. Menurut Logical Frame of The Nutritional Problems dari Unicef 2013 menyebutkan bahwa dampak tersebut bisa menyebabkan dampak jangka pendek ataupun secara jangka panjang. Contoh dampak stunting yang terjadi dalam jangka pendek adalah perkembangan otak yang terhambat, IQ yang lebih rendah, system 
imunitas yang lemah dan angka morbiditas dan disabilitas yang tinggi. Sedangkan dampak jangka panjang yang dapat terjadi adalah akan menimbulkan perawakan pendek usia dewasa, kehilangan produktivitas dan perawatan kesehatan, lebih besar berisiko terkena diabetes dan kanker, lebih tinggi berisiko menyebabkan penyakit tidak menular, menimbulkan permasalahan kesehatan reproduksi, dan dampak yang lebih besar terjadi adalah akan menimbulkan pendek lintas generasi ${ }^{1}$.

Tujuan dari studi ini adalah untuk membandingkan IQ skor pada anak yang pendek karena gizi kronis (stunting) dengan anak normal. Tujuan dari penelitan ini adalah untuk membandingkan skor IQ pada anak dengan stunting dan normal. Penelitian ini telah melalui kajian etik Fakultas Kesehatan Masyarakat Universitas Sriwijaya, Palembang dengan No. 273/UN9.1.10?KKE/2019.

\section{METODE}

Penelitian ini adalah analitk observasional dengan desain unmatching case control, yaitu adalah desain yang membandingkan 2 kelompok (kasus dan kontrol). Penelitian dilakukan di bulan Agustus - Oktober 2019 di Kota Palembang. Populasi dalam penelitian ini adalah seluruh siswa SD Negeri di Kota Palembang. Sampel 150 yang terdiri dari 75 kasus stunting dan 75 kontrol dengan teknik pengambilan sample yaitu teknik consecutive sampling. Kriteria inklusi adalah anak sekolah dasar di tiga kecamatan Kota Palembang (Sukarame, Seberang Ulu 1 dan Seberang Ulu 2), usia 9-12 tahun untuk kelompok kasus menderita stunting dengan TB/U (heightfor-age) Z-score kurang dari -2SD, sedangkan untuk kelompok kontrol dengan status gizi normal. Variabel Stunting diukur menggunakan alat pengukur tinggi bada, serta pemanfaatan software untuk menganalisis nilai z-score dalam penentuan kategorik status gizi. Instrumen untuk menilai kecerdasan siswa menggunakan test CPM (Coloured Progressive Matrics), yaitu instrument secara khusus digunakan untuk menilai kecerdasan anak untuk usia 9-12 tahun, dan selanjutnya hasil pengukuran akan dibaca oleh Psikolog. Skor IQ dibagi menjadi dua kategori yaitu untuk anak dengan kecerdasan superior, di atas rata-rata dan rata termasuk dalam kategori rata-rata ke atas sedangkan anak dengan kecerdasan di bawah rata-rata dan rendah tergolong dalam kategori rata-rata ke bawah. Setelah data dikumpulkan kemudian dilakukan analisis data bivariate menggunakan chi-square.

\section{HASIL}

Tabel 1 menggambarkan distribusi frekuensi dari responden. Di mana dari 150 responden sebagian besar responden berusia 11 tahun $42,68 \%$, berjenis kelamin laki-laki $46,75 \%$, memiliki kecerdasan intelektual rata-rata ke atas $54 \%$. 
Tabel 1. Distribusi Karakteristik Responden

\begin{tabular}{lcc}
\hline Variabel & \multicolumn{2}{c}{ Jumlah } \\
\cline { 2 - 3 } & N & Persentase (\%) \\
\hline Usia & 74 & 49,3 \\
$9-10$ Tahun & 78 & 50,7 \\
$11-12$ Tahun & & \\
Jenis Kelamin & 70 & 46,75 \\
Laki-Laki & 80 & 53,3 \\
Perempuan & & 50 \\
Status Stunting & 75 & 50 \\
Stunting & 75 & 54 \\
Normal & & 46 \\
\hline Kecerdasan Intelektual & 81 & \\
Rata-rata ke atas & 69 & \\
Rata-rata ke bawah & & \\
\hline
\end{tabular}

Gambar 1 menunjukkan distribusi kategori kecerdasan berdasarkan CPM (Colored Progresive Matrics) test, di mana terdapat 5 kategori yaitu tinggi, di atas rata-rata, rata-rata, di bawah rata-rata dan rendah. Selanjutnya data tersebut dilakukan analisis bivariate dengan menggunakan analisis chi square di mana untuk memudahkan analisis skor IQ dibagi menjadi dua kategori yaitu untuk anak dengan kecerdasan superior, di atas rata-rata dan rata termasuk dalam kategori rata-rata ke atas sedangkan anak dengan kecerdasan di bawah rata-rata dan rendah tergolong dalam kategori rata-rata ke bawah.

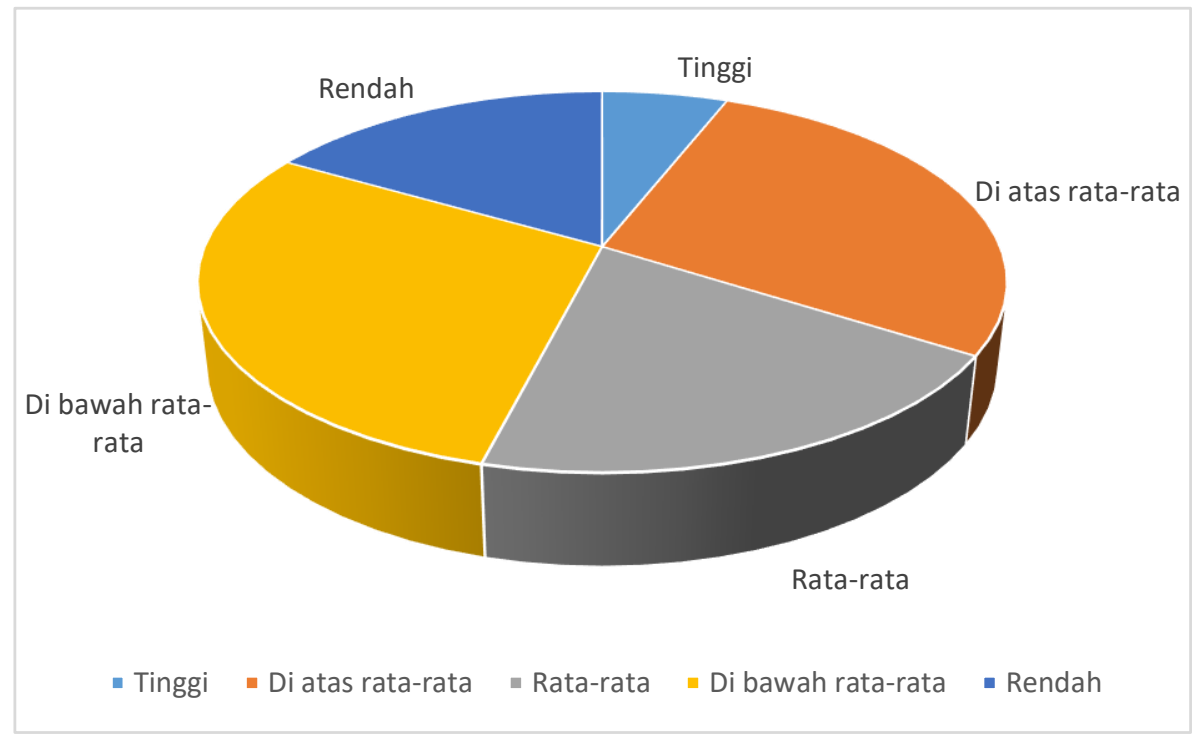

Gambar 1 Distribusi Kategori IQ berdasarkan CPM Test 
Tabel 2 menunjukkan bahwa anak yang pendek/stunting yang mendapatkan nilai skor IQ rata-rata ke atas adalah sebesar $64 \%$ dan yang mendapatkan nilai skor IQ rata-rata ke bawah sebesar $36 \%$. Sedangkan pada anak yang tidak stunting yang mendapatkan nilai IQ rata-rata ke atas adalah $72 \%$ dan yang mendapat nilai IQ rata-rata ke bawah adalah $28 \%$. Dari hasil uji statistik menunjukan adanya hubungan yang bermakna antara stunting dengan kecerdasan intelektual pada anak. Hal ini terliht dari nilai $p=$ 0.000 , sedangkan nilai OR yang didapatkan adalah 4,57 (95\% Cl:2,1733-9,6873). Artinya adalah anak-anak yang stunting berisiko 4,57 kali untuk mendapatkan kecerdasan intelektual ratarata ke bawah dibandingkan pada anak yang tidak stunting.

Tabel 2 Hubungan antara Stunting dan Skor IQ

\begin{tabular}{|c|c|c|c|c|c|c|}
\hline \multirow{2}{*}{\multicolumn{2}{|c|}{ Variabel }} & \multicolumn{2}{|c|}{ Skor IQ } & \multirow[t]{2}{*}{ Total } & \multirow[t]{2}{*}{ OR $(95 \% \mathrm{Cl})$} & \multirow[t]{2}{*}{ Nilai $p$} \\
\hline & & Rata-rata ke bawah & Rata-rata ke atas & & & \\
\hline \multicolumn{7}{|c|}{ Status Anak } \\
\hline- & Stunting & $48(64 \%)$ & $27(36 \%)$ & 75 & $4,57(2,1733-$ & $0.000^{*}$ \\
\hline- & Normal & $21(28 \%)$ & $54(72 \%)$ & 75 & $9,6873)$ & \\
\hline Jumle & & 69 (46\%) & $81(54 \%)$ & 50 & & \\
\hline
\end{tabular}

\section{DISKUSI}

Pada penelitian ini penilaian stuting dilakukan dengan melakukan pengukuran tinggi badan dengan posisi berdiri. Alat yang digunakan adalah alat pengukur tinggi badan microtoise yang diletakan di dinding. Posisi anak adalah berdiri tegap, pandangan lurus ke depan, kedua lengan berada di samping, posisi lutut tegak, kemudian memastikan kepala, punggung, bokong, betis dan tumit menempel di dinding dan responden dalam keadaan rileks. Keseragaman pengukuran ini dilakukan untuk menghindari bias dalam pengukuran. Setelah dilakukan pengukuran barulah dilakukan penilaian status gizi TB/U dengan kalkulator gizi disesuaikan dengan tanggal lahir dan jenis kelamin.

Dari besar kemaknaan pada penelitian ini menunjukkan bahwa stunting merupakan faktor risiko terjadinya kecerdasan anak usia sekolah dasar rata-rata ke bawah. Mengingat stunting yang terdeteksi pada anak telah mencapai usia sekolah dasar, tentu saja kekurangan gizi kronis sudah terjadi sejak lama atau bahkan mungkin sejak di dalam kandungan. Kekurangan gizi kurang tersebut pada tingkat tertentu dapat menyebabkan berat otak, jumlah sel, ukuran besar sel dan zat-zat biokimia lainnya lebih rendah daripada anak yang normal. Semakin lama anak terkena kekurangan gizi semakin 
berat akibat yang akan ditimbulkannya ${ }^{8}$. Menurut penelitian oleh Piaculy 2013, Stunting merupakan gangguan pertumbuhan yang dapat mengindikasikan adanya gangguan pada organorgan tubuh. Salah satu organ yang paling cepat mengalami kerusakan pada kondisi gangguan gizi ialah otak. Otak merupakan pusat syaraf yang sangat berkaitan dengan respon anak untuk melihat, mendengar, berpikir, serta melakukan gerakan ${ }^{9}$. Menurut penelitian terdahulu kekurangan gizi pada masa anak-anaknya akan menyebabkan tingkat intelektual mereka menurun 10-15 IQ point dengan risiko tidak dapat mengadopsi ilmu pengetahuan. Selain itu daya pikirpun akan sangat lemah akibat defisiensi atau kekurangan berbagai micron nutrient seperti yodium, Fe dan KEP 4 .

Penelitian oleh Yunitasari (2012), menyebutkan tidak ada perbedaan intelligence Question (IQ) antara anak stunting dan tidak stunting di SD Negeri Buara 04 Kecamatan Ketanggungan Kabupaten Brebes. ${ }^{10}$ Menurut penelitian tersebut hubungan kecerdasan lebih berpengaruh pada anak yang tingkat konsumsi energi rendah, perbedaan dan konsumsi Fe. Menurut teori, stunting akan menimbulkan perkembangan otak yang tidak maksimal. Bisa saja pada penelitian ini tidak ada hubungan antara stunting dengan kecerdasan IQ disebabkan oleh beberapa faktor, misalnya pada saat pengukuran, sampel yang tidak bisa mengeneralisir, dan faktor-faktor social budaya lainnya. Tapi hasil yang menyebutkan kekurangan energy protein dan $\mathrm{Fe}$, menguatkan bahwa malnutrisi jangka panjang akan mempengaruhi kecerdasan seseorang.

Upaya pencegahan untuk meminimalisir kerusakan yang lebih luas adalah dengan memberikan edukasi kepada orang tua mengenai gizi pada anak, pemberian makanan tambahan pada anak di sekolah, kunjungan rumah oleh petugas kesehatan.

\section{KESIMPULAN}

Anak yang pendek/stunting yang mendapatkan nilai IQ rata-rata ke atas adalah sebesar $64 \%$ dan yang mendapatkan nilai IQ rata-rata ke bawah sebesar 36\%. Sedangkan pada anak yang tidak stunting yang mendapatkan nilai IQ rata-rata ke atas adalah $72 \%$ dan yang mendapat nilai IQ rata-rata ke bawah adalah 28\% ( $p=0.000$, OR:4,57 (95\% Cl:2,1733-9,6873).

Dengan demikian perlu adanya perhatian khusus untuk mencegah terjadinya stunting pada anak terutama pencegahan pada anak usia kurang dari 2 tahun mengingat dampak yang sukar diperbaiki jika kondisi tersebut berlangsung lama atau kronis

\section{DAFTAR PUSTAKA}

1. Trihono;, Atmarita;, Tjandarini DH, Irawati A, Utami NH, Tejayanti T, et al. Pendek (Stunting) di Indonesia, Masalah Dan Solusinya. Jakarta: Lembaga Penerbit Badan Penelitian dan Pengembangan Kesehatan (Balitbangkes) 2015; 2015.

2. UNICEF. United Nation International Children's Emergency Fund. Annual Report 2009 UNICEF Division Communication; New York, USA2009. 
3. RISKESDAS. Laporan Hasil Riset Kesehatan Dasar (RISKESDAS). In: KemenkesRI, editor. Jakarta: Badan Penelitian dan Pengembangan Kesehatan 2018.

4. Kasdu D. Anak cerdas: Niaga Swadaya; 2004.

5. Yanuarita A. Rahasia otak dan kecerdasan anak. Yogyakarta: Teranova Books. 2014.

6. Devi N. Gizi Anak Sekolah Jakarta: EGC; 2012.

7. Suarca K, Soetjiningsih S, Ardjana IE. Kecerdasan majemuk pada anak. Sari Pediatri. 2016;7(2):85-92.

8. Husaini YK, Sulaeman Z, Basuki SM, Karyadi D, Matulessy P, Samsudin. Outpatient rehabilitation of severe protein energy malnutrition (PEM). Food and nutrition bulletin. 2006;8(2):1-6.

9. Picauly I, Toy SM. Analisis determinan dan pengaruh stunting terhadap prestasi belajar anak sekolah di Kupang dan Sumba Timur, NTT. Jurnal Gizi dan Pangan. 2013;8(1):55-62.

10. Yunitasari L. Perbedaan Intelligence Quotient (Iq) antara Anak Stunting dan Tidak Stunting Umur 712 Tahun di Sekolahdasar (Studi pada Siswa SD Negeri Buara 04 Kecamatan Ketanggungan Kabupaten Brebes). Jurnal Kesehatan Masyarakat Universitas Diponegoro. 2012;1(2). 